\section{Article}

IQBAL, J.1,3* (D)

SHAH, A. ${ }^{2}$

SARVAT, R. ${ }^{2}$

ADNAN, M. ${ }^{2}$

PARVEEN, N. ${ }^{1}$

NUZHAT, R. ${ }^{2}$

\title{
Documentation of Folk Herbal Uses of Medicinally IMPORTANT WILD VEgetableS USED BY THE TRIBAL Communities of Sargodha Region, Pakistan
}

\author{
Documentação de Usos de Ervas Populares de Vegetais Silvestres de \\ Importância Medicinal Usadas pelas Comunidades Tribais da Região de \\ Sargodha, Paquistão
}

\begin{abstract}
This preliminary study provides the traditional consumption of wild vegetables that mostly grow as weeds $(>50 \%)$ and that are also medicinally important in the rural communities of Sargodha region, Pakistan. Through different surveys and interviews with key informants, data on perception, gathering, preparation and use of 40 wild vegetables belonging to 27 families were collected. Most common wild occurring family was Cucurbitaceae. The most of the plants found were from herbs followed by trees and shrubs. According to mode of consumption, majority of the plants are cooked while others are used as in salads form while juices, spices, pickles, raw form (their parts like fruits), jams etc. are also used. Most commonly used plant parts were fruits followed by shoots and leaves. According to medicinal view of collected wild vegetables, most of the plants are used for gastrointestinal disorders. The present study confirms the findings that the rural communities can harvest wild edible plants especially weeds as a survival strategy. It presents the baseline data on the use of plant resources as wild edible vegetables by the native communities of the area. Moreover, many potential medicinal plants should be the focus of future research, especially from the phytochemical point of view for boosting pharmaceutical industries.
\end{abstract}

Keywords: wild vegetables consumption, medicinal plants, cucurbitaceae.

RESUMO - Este estudo preliminar fornece o consumo tradicional de vegetais silvestres que crescem principalmente como plantas daninhas (> 50\%) e que também são medicinalmente importantes nas comunidades rurais da região de Sargodha, Paquistão. Por meio de diferentes pesquisas e entrevistas com informantes-chave, foram coletados dados sobre percepção, coleta, preparação e uso de 40 vegetais silvestres, pertencentes a 27 famílias. A família de ocorrência silvestre mais comum foi a Cucurbitaceae. As plantas mais frequentemente utilizadas foram as ervas, seguidas de árvores e arbustos. De acordo com o modo de consumo, a maioria das plantas é cozida, enquanto outras são usadas na forma de saladas, enquanto sucos, temperos, picles, forma crua (suas partes como frutas), geleias, etc. também são usados. As partes de plantas mais comumente usadas foram frutas seguidas de brotos e folhas. De acordo com a visão medicinal dos vegetais silvestres coletados, a maioria das plantas é utilizada para distúrbios gastrintestinais. O presente estudo confirma a descoberta de que as comunidades rurais colhem plantas silvestres comestíveis, sobretudo plantas daninhas, como uma estratégia de sobrevivência. Ele apresenta os dados de base sobre o uso de recursos vegetais, como vegetal

${ }^{1}$ HigherEducation Department, Government of Punjab, Punjab, Pakistan; ${ }^{2}$ University of Sargodha, 40100, Sargodha, Pakistan;

${ }^{3}$ Shenzhen University, Shenzhen, P.R China. 
comestível silvestre, pelas comunidades nativas da área. Além disso, muitas plantas medicinais em potencial devem ser o foco de pesquisas futuras, especialmente do ponto de vista fitoquímico, para impulsionar as indústrias farmacêuticas.

Palavras-chave: consumo de vegetais silvestres, plantas medicinais, cucurbitáceas.

\section{INTRODUCTION}

There are about 3,000 species of wild plants that have been used as wild vegetables by human beings throughout the history while 200 species are domesticated as food crops (Simpson, 1995). The nutritive value of wild vegetables is tremendous, providing vital vitamins and mineral salts that are essential components of a balanced diet. The systematic documentation of indigenous knowledge regarding the identity and use of wild foods by rural communities is now an urgent concern (Shrestha and Dhillion, 2006) because both indigenous knowledge and the biological resources are diminishing due to habitat destruction and a disinterest among the younger generation. The utilization of wild plants and animals greatly benefit the society of today, from processes mostly involving local experimentation through indigenous and local knowledge (Kristensen and Balslev, 2003; Scherrer et al., 2005).

Since last two decades, there is a lot of environmental stress on wild edible plants due to population explosion and climatic change. Thus sustainable consumption of wild edible plants could ease this burden. According to the World Health Organization (WHO, 2000), mineral deficiency is associated with a large number of diseases such as cardiovascular disorder, diabetes, hypertensive disorders of pregnancy, anemia, premature births, delayed sexual maturation and behavioral changes observed in developing and under-developing countries. It is recommended that human diets must include sufficient nutrients for health maintenance, growth and body functions. In some low-income countries, however, the diet is dominated by a single staple food and is shared in minor amounts of other food items, resulting in a monotonous diet and a high risk of insufficient intakes of both macronutrients and micronutrients (Larsen et al., 2003). Lack of a data-bank on the chemical composition of edible wild plants is a major constraint in evaluating their significance in current diet and thus the decision whether to include them in the dietary recommendation.

In the current era of scientific advancement, wild food plants are still not only considered as simple nutritional intake, but also as a potential source of healthy and natural products (Tapsell et al., 2006; Heinrich and Prieto, 2008). The documentation and study of these products underly new trends in current food plant science (Colombo and Perego, 2009). According to modern nutritional studies, the consumption of leafy vegetables either wild or domesticated, brings numerous health benefits, and their everyday consumption in diet is highly recommended (Block, 1991).

Wild edible plants may have great potential as a source of unusual colors and flavours, bioactive compounds and as sources of dietary supplements or functional foods (Salvatore et al., 2005). In this regard, there is a great variety of wild non-cultivated plants that have been employed in the diet and traditional medicines (Pardo de Santayana, 2003). Most of these plant species are good candidates as functional ingredients and could be included in the modern diet (Turner et al., 2011). However, for these wild plants to become an alternative source for the food industry, broader knowledge about their physicochemical, antioxidant and nutritional properties is necessary (Martins et al., 2011).

There is little available literature about the documentation and comprehensive mineral and nutrient content of many wild plants. The aim of the present study is to document the folk herbal uses of plants that are being used as wild vegetables by the local communities of Sargodha region of Pakistan. The study will not only explore the wild edible flora of the given area but also help to identify the plant species which are locally used as wild vegetables and also reveal their ethnomedicinal value. Finally, it will also highlight the conservation status of these valuable plants and consequently address conservation issue of the study area. 


\section{MATERIALS AND METHODS}

The study was conducted in Sargodha region situated in Punjab province of Pakistan. This division comprises four districts, viz., Sargodha, Khushab, Mianwali and Bhakkar with covered area of $26,360 \mathrm{~km}^{2}$ and positioned between $71^{\circ}$ and $73^{\circ} \mathrm{E}$ longitude and $31^{\circ}$ and $33^{\circ} \mathrm{N}$ latitude, and is spread over the mountains area of Salt and Surghar Range and desert area of Thal (Figure 1). Additionally, the River Sindh and the River Jhelum are the most significant and only permanent rivers in the area, while Namal, Ochhali, Jhalar and Khabeki are the most famous lakes of the area.

Data regarding wild edible vegetables were collected from four districts of Sargodha region from 2015 to 2016 from the indigenous people of the area. To record the ethno-medicinal information, the participant observation method was used in combination with open-ended interviews and questionnaires. Additionally, other knowledgeable people of the region, including medicinal herb vendors, shepherds, and herbalists were among interviewees.

The people of local area speak different languages like Punjabi, Saraiki, Pashto and Urdu. Therefore, the interviews were in the native languages. A total of 75 informants (55 males and 20 females) from 25 to above 55 years were interviewed (Figure 2). Information of the ethnic use, common name, part used, growing season of the plants for the collection of specimen, mode of administration and locally used recipes were inquired and documented (Martin, 1995). After photography in their natural habitat, collected plant specimens were pressed, dried and mounted on herbarium sheets as voucher specimens. Botanical names of collected plant specimens were confirmed with help of "Flora of Pakistan" (Ali and Qaisar, 1993-2009). The list of plant species was checked and updated after verification from the online website (http:/ /www.theplantlist.org) of the Royle Botanic Garden, Kew, assessed on April 3, 2014. The specimens were preserved for future reference at the Sargodha University Herbarium, Pakistan for future reference.

Data regarding wild edible plants that were mostly weeds and used as vegetables were stored in Microsoft Excel 2007 and presented by using percentages, frequency, ranking and bar charts.

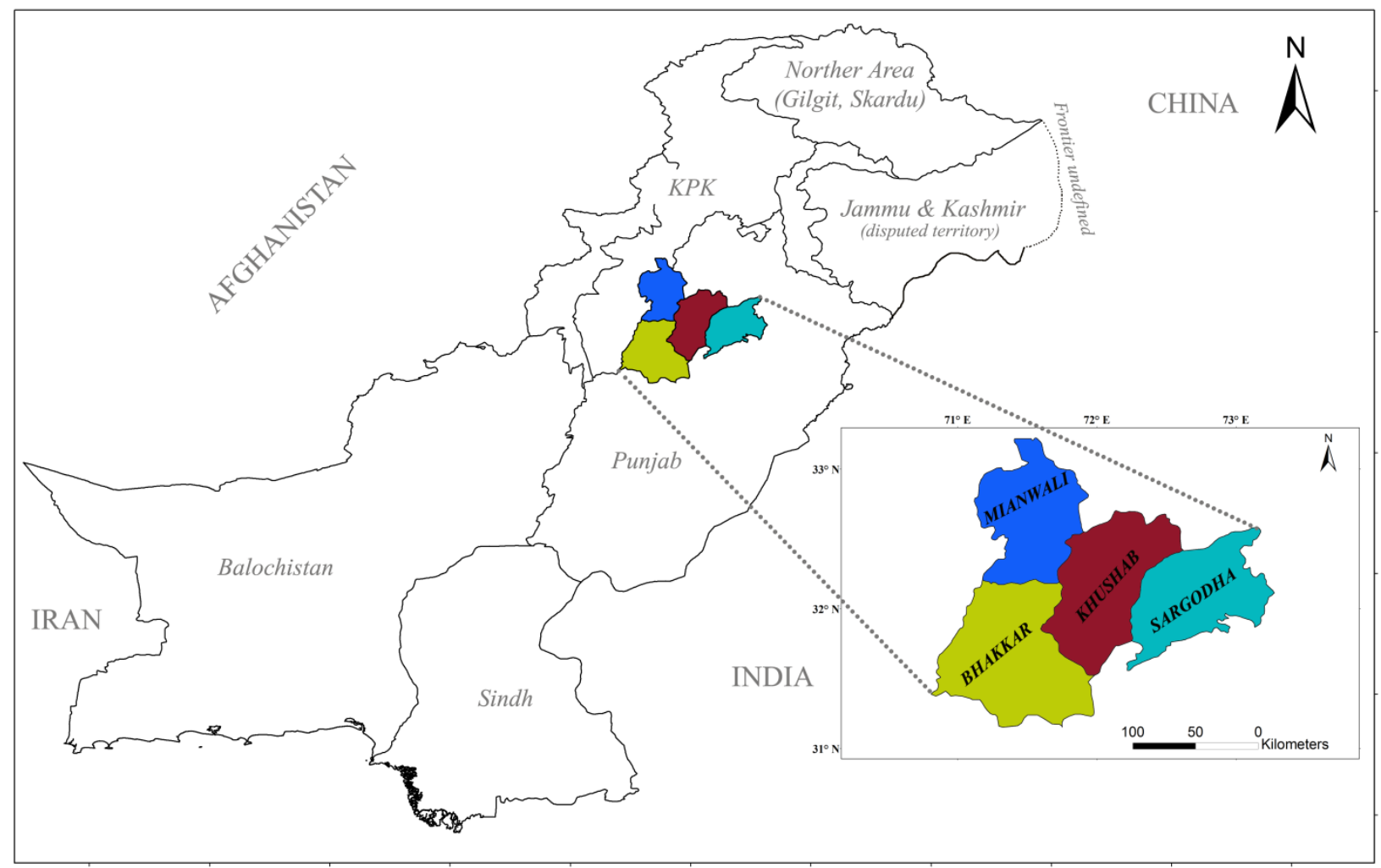

Figure 1- Map of Sargodha region, Punjab, Pakistan. 


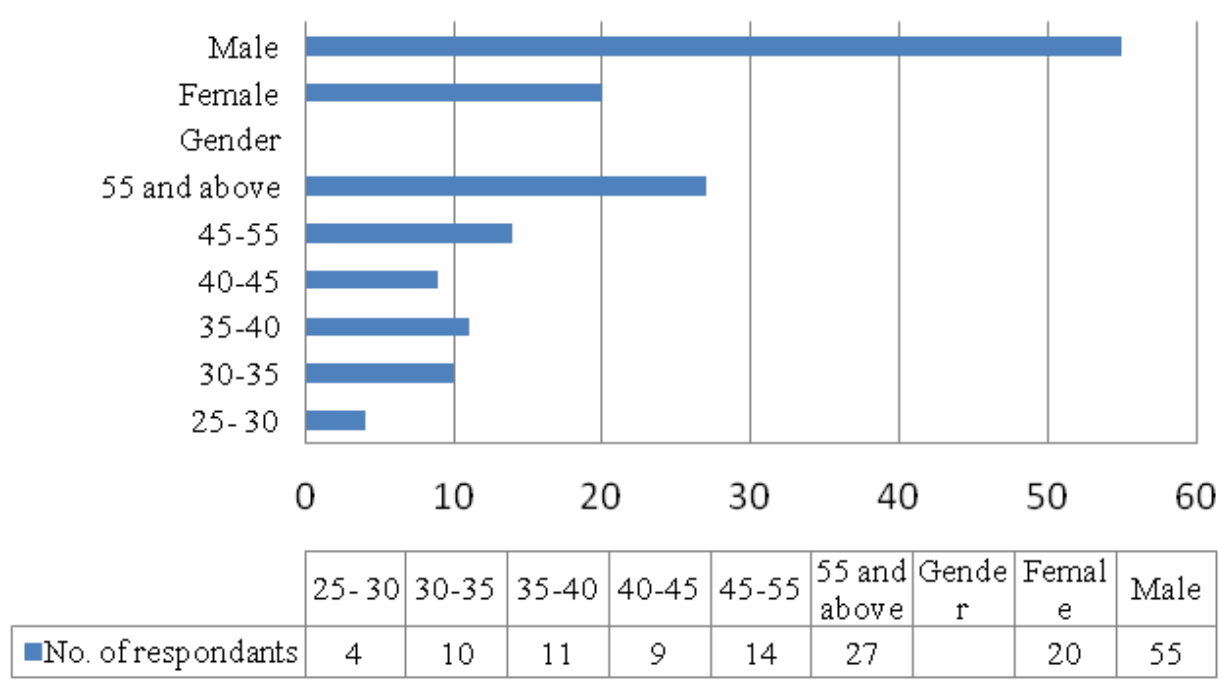

Figure 2- Socio-economic characteristic of the study sample, $\mathrm{N}=75$.

\section{RESULTS AND DISCUSSION}

Figure 2 illustrates the demographic characteristics of the participants. Of the seventy five participants, $73 \%$ were males and $26 \%$ were females with different age groups from 25 to 55 and above.

A total of 40 wild plants belonging to 27 families were reported whose uses as medicinally important wild vegetables were mentioned by more than two informants (Table 1).

With respect to diversity of the species gathered, Cucurbitaceae was the highly cited botanical families, (4 species) followed by Apiaceae, Fabaceae and Lamiaceae (3 species each), Amaranthaceae, Capparaceae, Polygonaceae, Solanaceae (2 species each). While nineteen families, viz. Apocynaceae, Arecaceae, Asteraceae, Brassicaceae, Chenopodiaceae, Euphorbiaceae, Lythraceae, Malvaceae, Moraceae, Moringaceae, Myrtaceae, Oleaceae, Oxalidaceae, Portulacaceae, Plantaginaceae, Salvadoraceae, Sapindaceae, Typhaceae, Xanthorrhoeaceae were presented by one species each. The majority of wild species were herbs $(72 \%)$ followed by trees $(23 \%)$ and shrubs $(5 \%)$. High percentage of plant parts used as vegetables and medicines was fruits $37 \%$, followed by shoots $(28 \%)$, leaves $(23 \%)$, seeds $(5 \%)$, floral buds $(3 \%)$ and corms and rhizome (2\% each) (Figures 3, 4 and 5$)$.

Among the reported plant species mostly were consumed in cooked form because in mostly tribal areas gathering and cooking the wild plants is daily activity. It was observed that more than $70 \%$ of reported plant species were used in cooked form to fulfill the requirement of food as well as many common ailments. And the others are used in raw form as salad or used to make pickle or jams. Pickle and jams are considered the best way to preserve the edible plants for long time period. Weeds are used in cooked form as delicious dish called "saag". Amaranthus viridis, Chenopodium album, Cleome gynandra, Coriandrum sativum, Digera muricata, Mentha longifolia, Mentha piperita, Oxalis corniculata, Portulaca oleracea, Rumex dentatus, Rumex vesicarius, Sonchus oleraceus and Typha latifolia are the most common leafy vegetables in the study area. Special local and delicious dish "Boori" is prepared from Typha latifolia fruit. Fruits of Syzygium cumini, Sapindus trifoliatus, Salvadora persica, Punica granatum, Physalis emblica, Phoenix sylvestris, Olea ferruginea, Momordica balsamina, Ficus racemosa, Cucumis melo and Capparis decidua are important part of tribal diet. Wild vegetables are used both as food and medicine to fulfill the livelihood needs and to cure various ailments. The most common aliment category treated by using these plants was gastrointestinal problems. The highest percentage of gastrointestinal problems like stomach disorders, constipation and others is due to unavailability of safe and clean drinking water to rural communities of Sargodha region. Some other important ailments treated by using wild vegetables are diabetes, skin problems liver problems and others (Table 1). Mostly medicinal plants are used in various remedies in fresh form as the fresh plant parts are cooked as vegetables. This is because that wild plant species are easily accessible to the inhabitants in growing season. 
IQBAL, J. et al. Documentation of folk herbal uses of medicinally important wild vegetables used by the tribal communities ...

Table 1- Plants used as wild vegetables in Sargodha region, Punjab, Pakistan

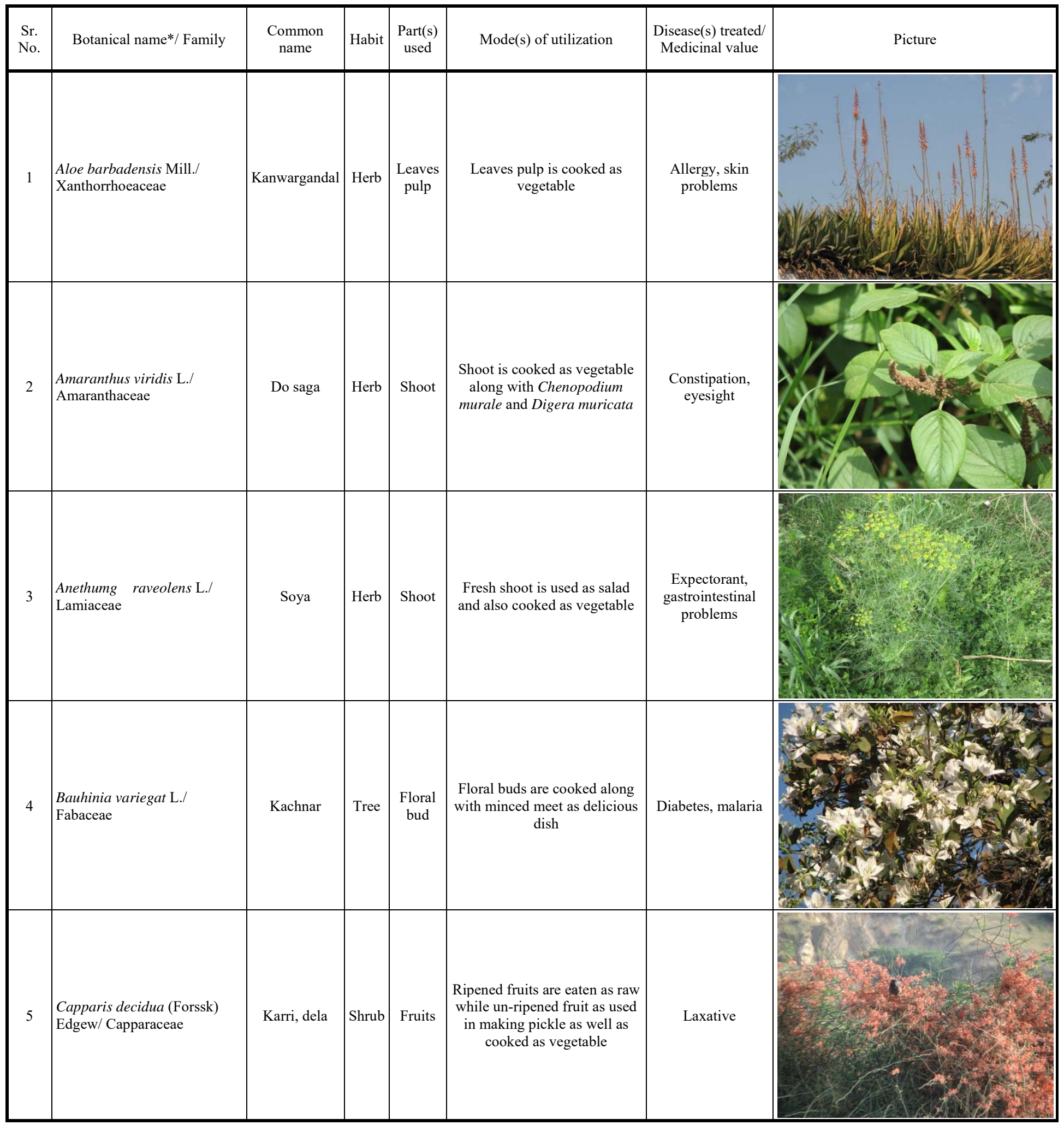


IQBAL, J. et al. Documentation of folk herbal uses of medicinally important wild vegetables used by the tribal communities ...

Table 1, cont.

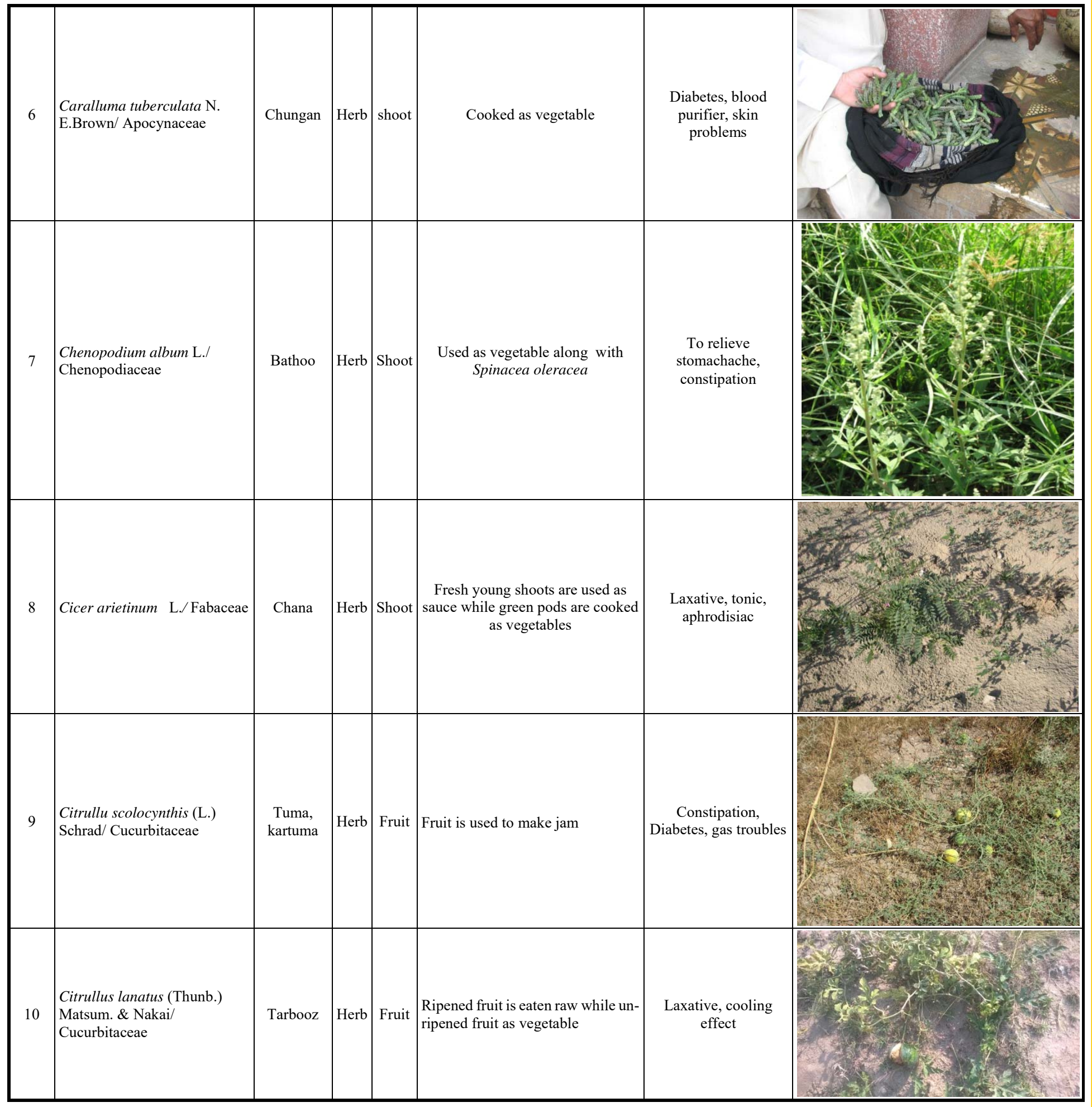


IQBAL, J. et al. Documentation of folk herbal uses of medicinally important wild vegetables used by the tribal communities ...

Table 1, cont.

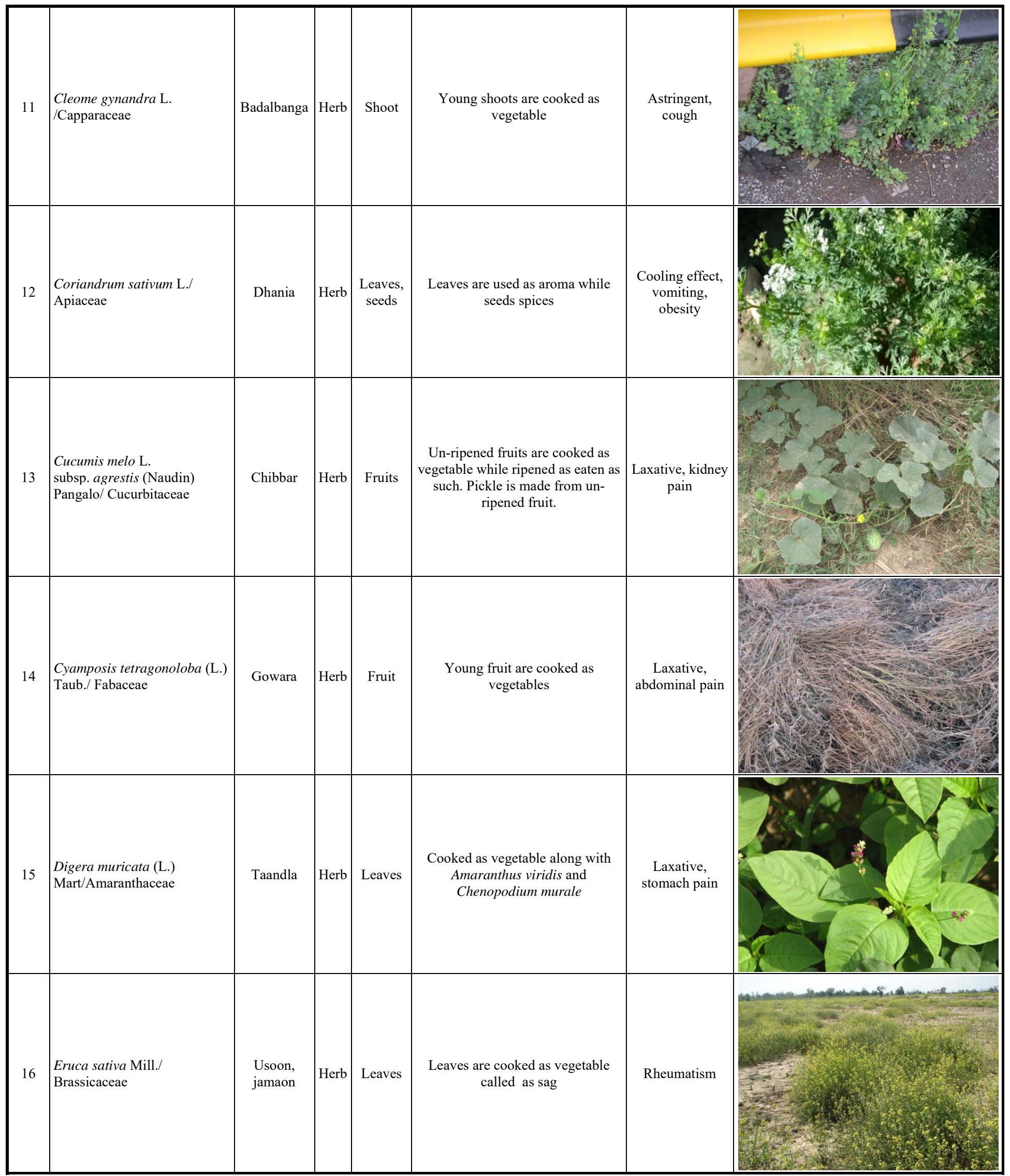


Table 1, cont.

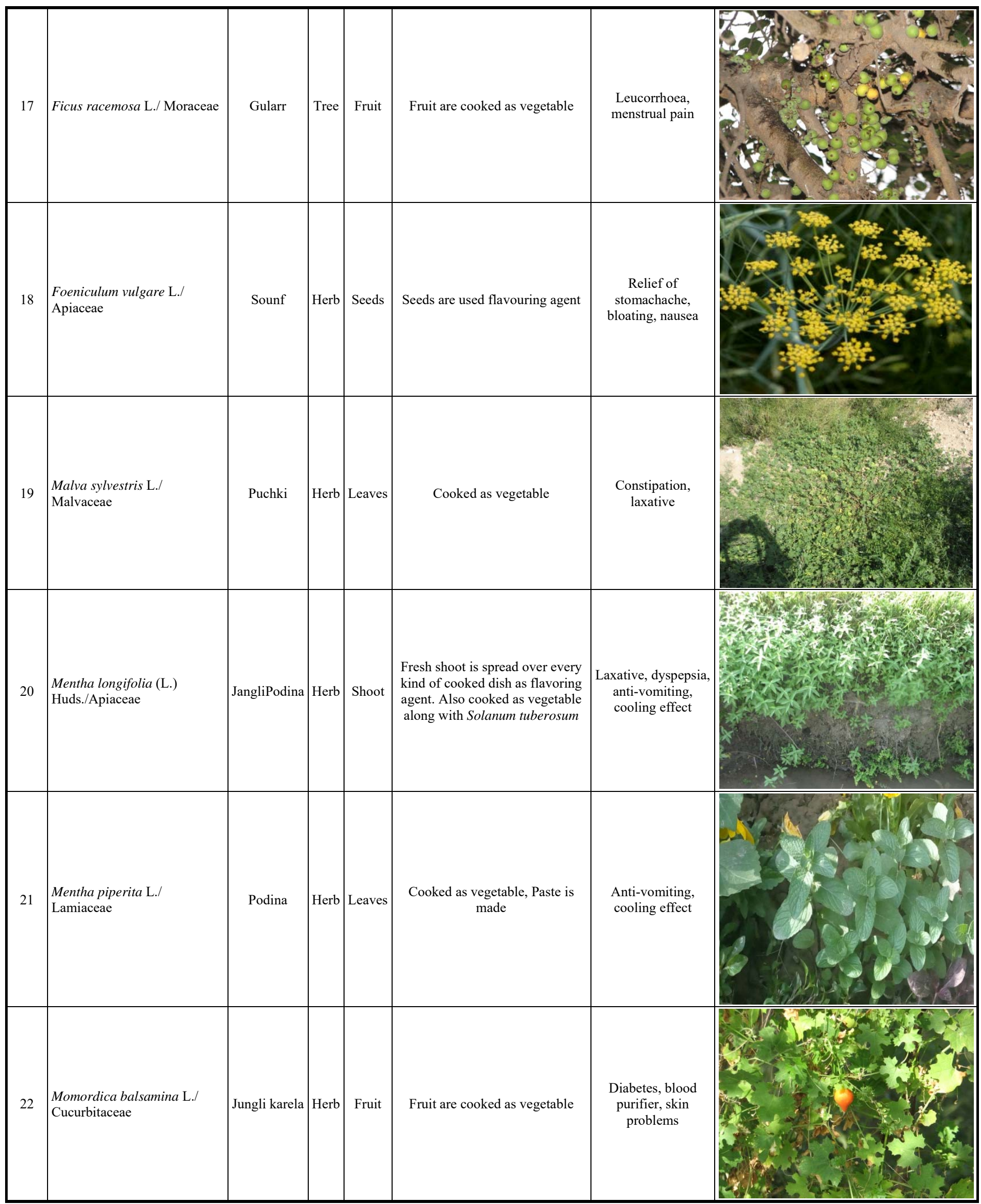


IQBAL, J. et al. Documentation of folk herbal uses of medicinally important wild vegetables used by the tribal communities ...

Table 1, cont.

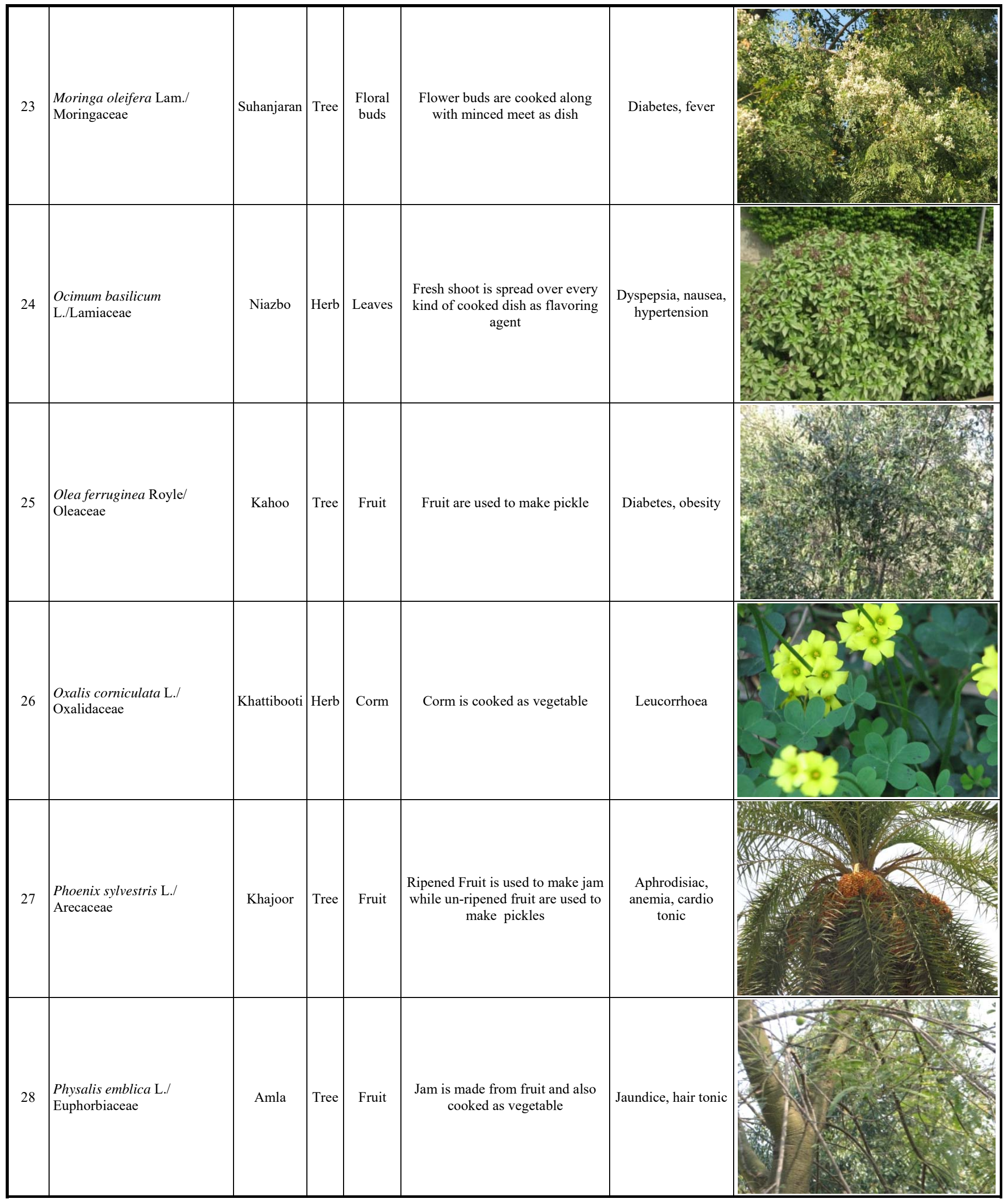


IQBAL, J. et al. Documentation of folk herbal uses of medicinally important wild vegetables used by the tribal communities ...

Table 1, cont.

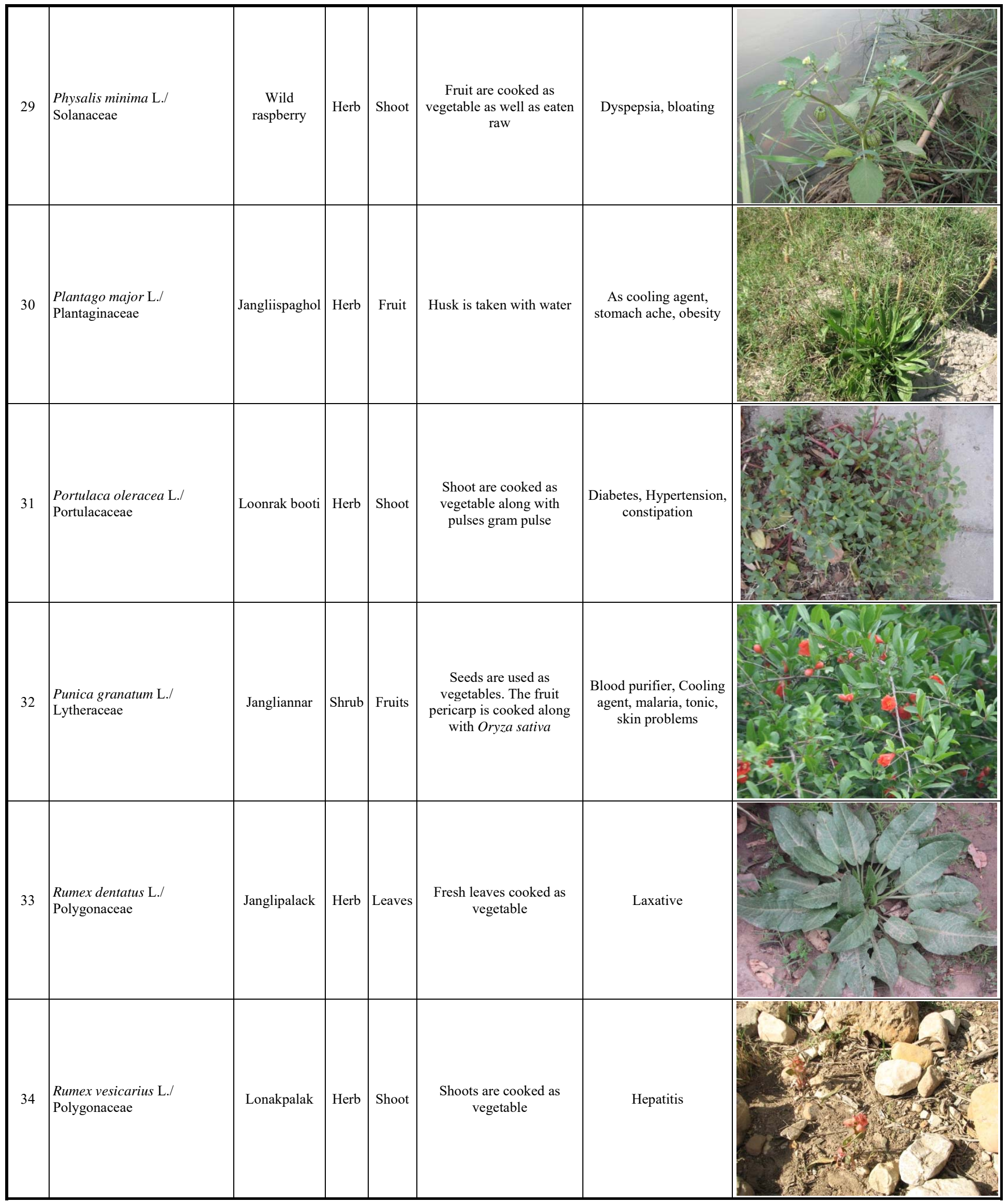


IQBAL, J. et al. Documentation of folk herbal uses of medicinally important wild vegetables used by the tribal communities ...

Table 1, cont.

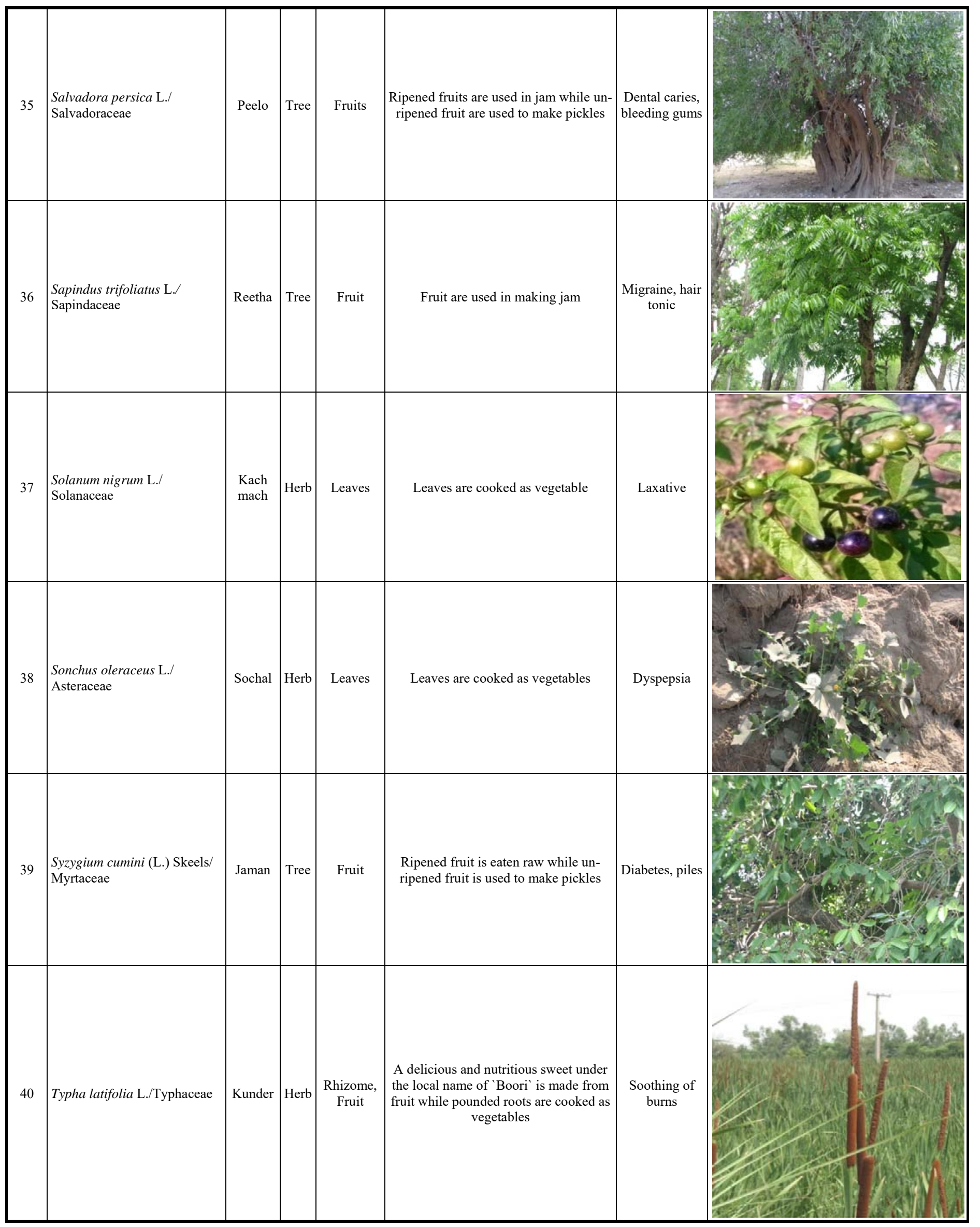




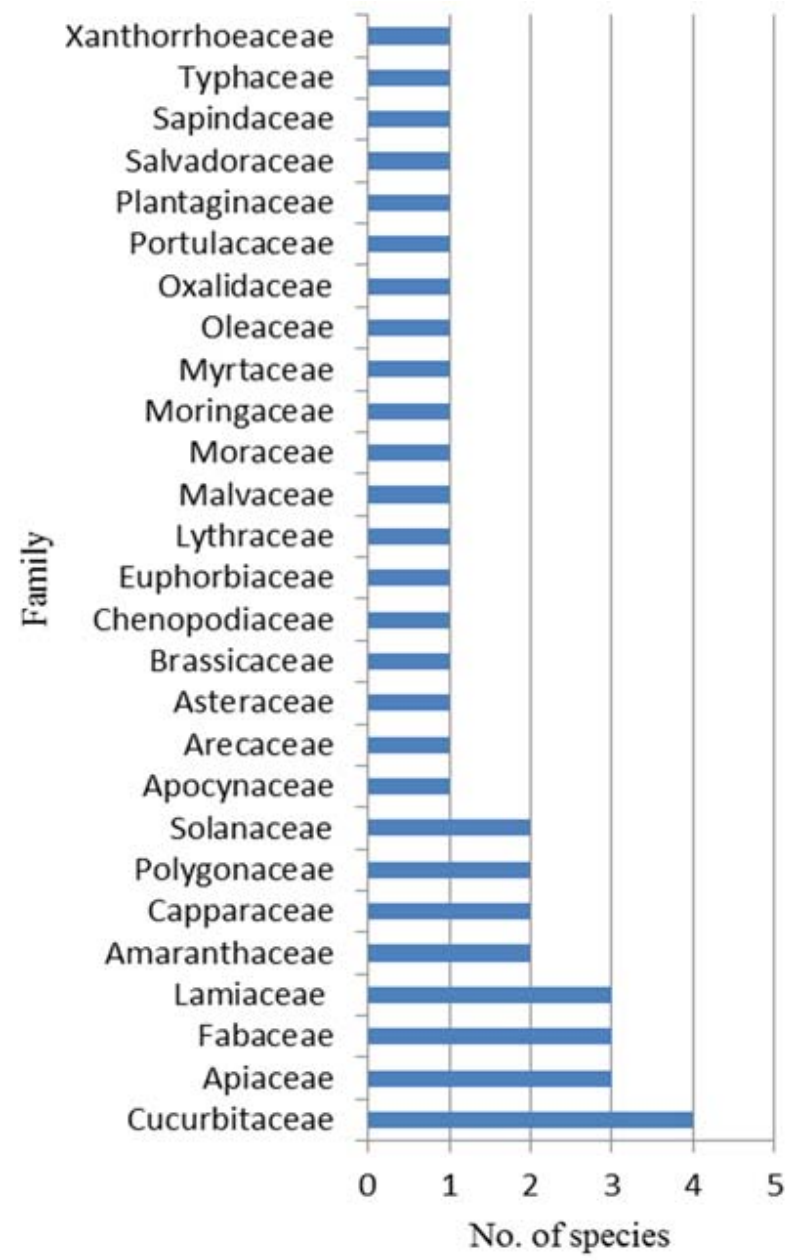

Figure 3 - Diversity of medicinal plants species.

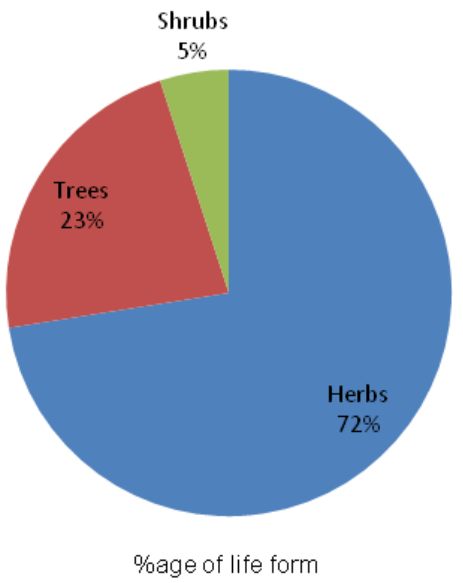

Figure 4 - Diversity of life forms.

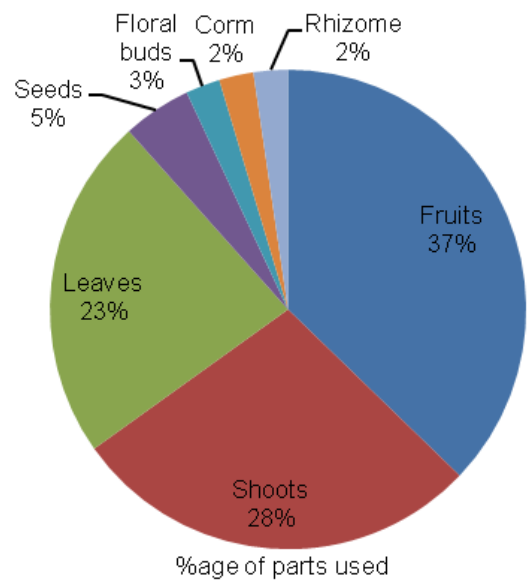

Figure 5 - Parts used reported plants species.

It was observed that inhabitants of the study area have a vast knowledge of using medicinal plants for treating various illnesses due to lack of modern communications, poverty and unavailability of modern healthcare facilities. And many people believe that such plants have more powerful healing properties when collected from the wild (Pardo de Santayana et al., 2005). The majority of wild vegetables used in study area were weedy species that grow commonly in crop fields, home gardens, roadsides (Giday et al., 2010). Moreover, often abundant near at hand, easy to harvest and are frequently rich in bioactive (Voeks, 2004). However, according to inhabitants the increasing use of herbicides and continued use of forming plots without leaving some fellow lands due to increasing shortage of agricultural plots is potential threat to medicinal flora of the study site. The use of herbicides to control weeds in various crops by using chemical method is very common today and these herbicides not damage the weeds only but also cause stress in tolerant cultivars of crops (Agostinetto et al., 2016). This chemical control of weeds may cause a serious threat to plant species used for food and medicine by local communities. Results showed that men have better medicinal plants knowledge as compared to women this could be due to the reason of cultural norms of the study area as women have limited social life or exposure in study area. It is observed that younger generation has a little or no knowledge about medicinal plants due to acculturation. So for only a limited number of studies have been conducting in Pakistan regarding medicinal uses of weeds (Khan et al., 2013; Islam et al., 2006; Ahmad et al., 2006). There is a dire need of documentation of traditional knowledge of medicinal flora in various communities of Pakistan before it is vanished.

It can be concluded from the study that the Sargodha Region has highly specialized indigenous vegetation with varied medicinal values. This Region has great potential for cultivation of different kinds of medicinal plants as well as has a large variety of wild vegetables. Biodiversity in the Region is under the perpetual stress of drought and unsustainable use. The present study 
proved very fruitful in exploring the intimate integration of affiliation and dependence of rural people on the wild plant resources as their food and medicinal care. According to medicinal view of collected wild vegetables, $40 \%$ plants were used for gastrointestinal diseases, followed by glandular disorders (10\%), dermatological disorders $(9 \%)$, cardiovascular disorders $(7 \%)$, liver problems $(9 \%)$, sexual disorders $(5 \%)$, respiratory disorders and fever $(3 \%)$, oral problems $(2 \%)$ and others $(11 \%)$ (Figure 6). The rural people of this Region inherit a rich traditional knowledge and documentation of this knowledge has provided novel information from the area. This will not only provide recognition of this undocumented knowledge but will also help in conservation of such rare, gradually vanishing important species. It will also provide new pharmacological insights for better health care of human being regarding many ailments.

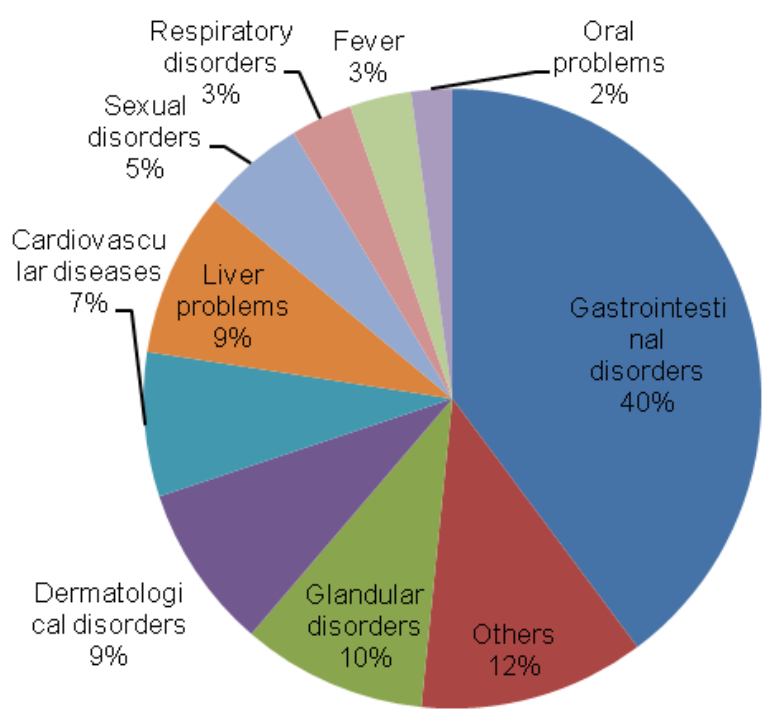

\%age of use reports of various diseases

Figure 6- Percentage of diseases treated by reported medicinal plants.

\section{REFERENCES}

Agostinetto D, Perboni LT, Langaro AC, Gomes J, Fraga DS, Franco JJ.Changes in photosynthesis and oxidative stress in wheat plants submmited to herbicides application. PlantaDaninha. 2016; 34(1):1:1-9.

Ahmad M, Khan MA, Zafar M, Sultana S.Ethnomedicinal demography and ecological diversification of some important weeds from district Attock Pakistan. Pak J Weed Sci Res. 2006; 12(1-2):37-46.

Ali SI, Qaiser M, editors. Flora of Pakistan. Islamabad, Karachi: 1993-2009. N.194-217.

Block G. Dietary guidelines and the results of food consumption surveys. Am J Clin Nutr. 1991; 53(1):S356S-S7.

Colombo ML, Perego S. Una sconosciuta nel piatto. ErboristeriaDomani. 2009; 337:44-51.

Giday M, Asfaw Z, Woldu Z. Ethnomedicinal study of plants used by Sheko ethnic group of Ethiopia. J Ethnopharmcol. 2010; 132(1):75-85.

Heinrich M, Prieto JM. Diet and healthy ageing 2100: will we globalise local knowledge systems. Ageing Res Rev. 2008; 7(3):24974.

Islam M, Ahmad H, Rashid A, Razzaq A, Akhtar N, Khan I Weeds and medicinal plants of Shawar valley, district Swat. Pak J Weed Sci Res. 2006; 12(1-2):83-8.

Khan J, Khan R, Qureshi RA. Ethnobotanical study of commonly used weeds of District Bannu, Khyber Pakhtunkhwa (Pakistan). J Med Plants Stud. 2013; 1(2):1-6.

Kristensen M, Balslev H. Perceptions, use and availability of woody plants among the Gourounsi in Burkina Faso. BiodiversConserv. 2003; 12(8):1715-39.

Larsen T, Thilsted SH, Biswas SK, Tetens I. The leafy vegetable amaranth (Amaranthusgangeticus) is a potent inhibitor of calcium availability and retention in rice-based diets. Br J Nutr. 2003; 90(3):521-7.

Martin Gl. Ethnobotany: A methods manual. People and plants' conservation manual. UNESCO; 1995

Martins D, Barros L, Carvalho AM, Ferreira ICFR.Nutritional and in vitro antioxidant properties of edible wild greens in Iberian Peninsula traditional diet. Food Chem. 2011; 125(2):488-94.

Pardo de Santayana MGO, Tardío J, Morales R. The gathering and consumption of wild edible plants in the Campoo (Cantabria, Spain).Int J Food SciNutr. 2005; 56(7):529-42. 
Pardo de Santayana MGO. Las plantas en la culturatradicional de la Antigua Merindad de Campoo [thesis]. Madrid: Universidad Autónoma de Madrid; 2003.

Salvatore S, Pellegrini N, Brenna OV, Del Rio D, Frasca G, Brighenti F, et al. Antioxidant characterization of some Sicilian edible wild greens. J Agric Food Chem. 2005:53(24)9465-71.

Scherrer AM, Motti R,Weckerle CS.Traditional plant use in the areas of Monte Vesole and Ascea, Cilento National Park (Campania, Southern Italy). J Ethnopharmacol. 2005; 97(1):129-43.

Shrestha PM, Dhillion SS. Diversity and traditional knowledge concerning wild food species in a locally managed forest in Nepal. Agrofor Syst. 2006; 66(1):55-63.

Simpson BB. Spices, herbs and perfumes. In: Simpson BB, Ogorzaly MC, editors. Economic botany: plants in our world. $2^{\text {nd. ed. }}$ New York: McGraw-Hill; 1995. P.278-301

Tapsell LC, Hemphill I, Cobiac L, Patch CS, Sullivan DR, Fenech M, et al. Health benefits of herbs and spices: the past, the present, the future. Med J Austr. 2006; 185(4 Suppl):S4-S24.

Turner NJ, Luczaj LJ, Migliorini P, Pieroni A, Dreon AL, Sacchetti LE, et al. Edible and tended wild plants, traditional ecological knowledge and agroecology. Crit Rev Plant Sci. 2011; 30(1-2):198-225.

Voeks RA. Disturbance pharmacopoeias: medicine and myth from the humid tropics. Ann Assoc Am Geogr. 2004; 94:868-88.

World Health Organization - WHO. World health report. Geneva: World Health Organization; 2000. 